\title{
The Effect of Macroeconomic Variables on Stock Prices in Emerging Sri Lankan Stock Market
}

\author{
L.M.C.S. Menike \\ Department of Accountancy \& Finance \\ Sabaragamuwa University, Belihuloya
}

\begin{abstract}
This study investigates the effects of macroeconomic variables on stock prices in emerging Sri Lankan stock market using monthly data for the period from September 1991 to December 2002. The multivariate regression was run using eight macroeconomic variables for each individual stock. The null hypothesis which states that money supply, exchange rate, inflation rate and interest rate variables collectively do not accord any impact on equity prices is rejected at 0.05 level of significance in all stocks.
\end{abstract}

The results indicate that most of the companies report a higher $\mathrm{R}^{2}$ which justifies higher explanatory power of macroeconomic variables in explaining stock prices. Consistent with similar results of the developed as well as emerging market studies, inflation rate and exchange rate react mainly negatively to stock prices in the Colombo Stock Exchange (CSE). The negative effect of Treasury bill rate implies that whenever the interest rate on Treasury securities rise, investors tend to switch out of stocks causing stock prices to fall. However, lagged money supply variables do not appear to have a strong prediction of movements of stock prices while stocks do not provide effective hedge against inflation specially in Manufacturing, Trading and Diversified sectors in the CSE. These findings hold practical implications for policy makers, stock market regulators, investors and stock market analysts.

\section{Introduction}

The relationship between macroeconomic variables and stock prices has been extensively studied in developed capital markets and literature on the above variables date back to 1970s. However, multifactor models have been developed as an explanatory factor of the variation in equity prices and these studies have typically focused on developed markets. The relationship between macroeconomic variables and stock prices has been examined in Emerging Stock Markets (ESMs) after 1980s. However, interest in investing in emerging markets has grown considerably over the past decade. Harvey (1995a) shows that returns and risks in ESMs have been found to be higher, relative to developed markets.

Numerous studies have been conducted to determine the determinant of stock price movements \{Chen et al, (1986), (2005); Fama and French, (1988), Bulmash and Trivoli, (1991); Hooker, (2004); Gjerde et al. (1999); Bilson et al. (2001); Asprem, (1989); Wasserfallen, (1989); Fama, (1981); Abdullah and Hayworth, (1993). All the studies cited above suggest that strong relationships exist between macroeconomic variables and stock prices in developed as well as ESMs. Although most of the studies were carried out in emerging market contexts recently, there is a paucity of such studies in emerging Sri Lankan Stock

(C) 2006 Sabaragamuwa University Journal, vol 6, no. 1, pp 50-67 50 
Market \{except a few - eg. Samarakoon, (1996 b, 1998 c, 1998 d); Samarakoon et al. (2000); Perera, (1994), Nimal, (1997), Premawardena; (1997)\}. This study extends these literatures by considering the relationship between stock prices and macroeconomic variables in the emerging Sri Lankan Stock Market. The study investigates the effect of selected macroeconomic variables such as money supply, exchange rate, inflation rate and interest rate on stock prices. The findings imply that there exists significant association between most of the macroeconomic variables and stock prices in the Colombo Stock Exchange (CSE).

The theoretical motivation for undertaking the study on the effect of macroeconomic variables on stock prices can be discussed as follows. The relations between exchange rate movements and stock prices are based on the rise in the domestic interest rate that leads to capital inflows and makes the exchange rate appreciate and this suggests that, for export dominant industries, currency appreciation has a negative effect on stock prices in such industries because of reduction in exports while currency appreciation boosts the stock market (positive effect on stock prices) for import dominant industries due to increase in imports. Numerous studies have been conducted in developed capital markets with regard to the relationship between stock prices and interest rates and results of most studies suggest that stock and bond returns are predictable and that one may be used to forecast the other. Whenever the interest rate on Treasury securities rises, investors tend to switch out of stocks, causing stock prices to fall.

The effects of inflation on the returns to financial assets has been an important theoretical issue for many years. The basic theoretical concept in this area is commonly attributed to Irving Fisher (1930) who posited that the nominal interest rate fully reflects the available information concerning the possible future values of the rate of inflation. This hypothesis has received wide acceptance among economists and has played an important role in the monetary theory, finance and macroeconomics. All the above considerations motivated to conduct this research study in the Sri Lankan context.

The above theoretical motivations and empirical evidence reveal relationships between stock prices and macroeconomic variables. This leads to undertaking the study of the effects of macroeconomic variables on stock prices in the Sri Lankan context. When considering the above facts, the results of a study of this nature will be of enormous importance to numerous parties. The findings of the study hold practical implications for various parties. Therefore, a study of this nature is timely and essential.

The stock exchange acts as the most important market for capital and a welldeveloped capital market is essential to promote economic development. The Sri Lankan government has been offering a number of incentives to boost the stock market. Specially, foreign investors are granted substantial incentives to invest in Sri Lankan company shares. The government has taken several significant steps to boost the Sri Lankan Stock Market. Further, the capital market plays an important part in the economy and companies listed in the CSE are already involved in the development of infrastructure - the Power Sector, Telecom, Water and Health while other sectors in the CSE cover a significant role in the Sri Lankan macroeconomic. By taking into consideration the above factors, the results of a study of this nature will be of enormous importance for both local and foreign investors, stock market regulators, multinational 
corporations, stock market analysts and policy makers. Therefore, this type of study is very essential to promote the stock market.

However, the paucity of literature on the effects of macroeconomic variables on stock prices and little attention of the responsible parties and the lack of knowledge of this issue in the Sri Lankan context could not be added to the information set available to the above parties. In order to fill this gap in the literature in the emerging Sri Lankan Stock Market, this study will add immensely to the existing literature of emerging Sri Lankan Stock Market. Therefore, the research problem of this study is to find out whether there is any relationship between macroeconomic variables and stock prices in the Colombo Stock Exchange. The primary objective of the study is to identify the impact of behaviour of macroeconomic variables on stock prices.

The remainder of the paper proceeds as follows: Section 2 reviews the literature; Section 3 describes the methodological issues and data used; Section 4 discusses the results. Finally, section 5 concludes the paper with implications and future research.

\section{Literature Review}

The literature of the effects of macroeconomic variables on stock returns dates back to the late 1970s. Studies were focused on developed, emerging and both developed and emerging capital markets context and the extant literature reveals strong relationships between the above macroeconomic variables and stock returns.

Nelson (1976) examined the relationship between monthly stock returns and inflation in the post-war period from 1953 to 1974 using US data, and found a negative relationship between stock returns, in both expected and unexpected inflation. The paper presented by Bodie (1976) defines the effectiveness of common stocks as an inflation hedge to the extent of which they can be used to reduce the risk of an investor's real return which stems from uncertainty about the future level of the price of consumption goods.

Fama (1981, 1982), Fama and Schwert (1977), Gallagher and Taylor (2002), Geske and Roll (1983) empirically find that stock returns are negatively affected by both expected and unexpected inflation. Based on the money demand and the quantity theory of money, Fama (1981) and Geske and Roll (1983) explain the negative linkage among stock returns and inflation. Using post-war data for the US, Canada, Germany and the UK, Kaul (1990) explains the relationship between stock returns and unanticipated changes in expected inflation under alternative monetary policy regimes. He finds that in countries where there is no change in the policy regime there exists a negative relation between stock returns and changes in expected inflation. Marshall (1992) finds that negative effect of inflation on stock return is generated by real economic fluctuations, by monetary fluctuations or changes in both real and monetary variables. Tanggaard (2002) finds a moderately positive relationship between expected stock returns and expected inflation for the US and a strong positive relationship for Denmark. Sharfe (2002) suggests that rise in expected inflation reduces equity prices in the US. The negative relationship between inflation and stock returns is supported by Chatrath et al. (1997)-India, Najandand and Noronhal (1998)-Japan, Zhao (1999) -China, Crosby (2001)-Australia and Adrangi et al. 
(1999) - Korea and Mexico. Further, Omran and Pointon (2001) - Egypt, Apergis and Eleftheriou (2002)-Greece.

Contrary to these studies Choudhry (2001) finds a positive relationship between stock returns and inflation in four high inflation countries. Boudoukh and Richardson (1993), Solnik and Solnik (1997), Engsted and Tanggaard (2002), Kim and In (2005) and Schotman and Schweitzer (2000) examined the relationship between stock returns and inflation over long-horizons and their results support the Fisher Hypothesis as the horizon widens. Samarakoon (1996) finds that nominal stock returns are positively related to expected inflation in a one-to-one correspondence in Sri Lanka.

Studies on money-stock market relationship centered on the question of whether money is a leading indicator of stock prices. Study by Homa and Jaffee (1971) supported the view that past increases in money lead to increase in equity returns. Cooper (1974) examined the money- stock market relationship using US data and found that the lead/ lag and cross spectra of stock returns and changes in money supply are consistent with the Efficient Market model and the Monetary Portfolio models in that stock returns anticipate changes in monetary returns. Rogalski and Vinso (1977) examined the reaction of stock prices to unanticipated changes in money and found results inconsistent with Sprinkel (1964), Homa and Jaffe (1971), and Hamburger and Kochin (1977) which has shown that past money changes do not contain predictive information on stock prices, upholding the Efficient Markets view. Pearce and Roley (1983) investigates whether the response of common stock prices to weekly money announcements is consistent with the Efficient Market Hypothesis. Chen et al. (2005), Bulmash and Trivoli (1991) and Barrows and Naka (1994) find a positive relation between money supply and stock returns. Rozeff (1984), Campbell (1987), Kaul (1987) and Booth and Booth (1997), confirmed the theory that an expansionary monetary policy increases stock returns.

The relations among stock returns, real activity, inflation and money supply changes were investigated by James et al. (1985), and their empirical results strongly support Geske and Roll's (1983) reversed causality model, which brings similar results with Solnik (1984) for other industrialized countries. Kaneko and Lee (1995) have re-examined the US and the Japanese markets and they employed the Chen et al. (1986) factors to evaluate the effects of systematic economic news on stock market returns. Using eight variable Vector Auto Regressive (VAR) system, they found that both the term and risk premiums, as well as the growth rate of industrial production, are significantly priced in the US.

Asprem (1989) examines the relationship between macroeconomic variables and stock prices in European countries and finds a positive relation between Industrial production, money supply and stock prices and a negative effect between inflation, interest rate and stock prices. Bulmash and Trivoli (1991) found that interest rates influenced stock prices negatively, since higher interest rates attract another investment alternative. Abdullah and Hayworth (1993) find that stock returns are positively related with money growth and inflation rate while interest rates react negatively on stock returns.

The existing finance literature is inconclusive on the relations between exchange rate movements and macroeconomic variables \{Aggarwal, (1981); Edison, (1991); Frenkel, (1983); Gandolfo et al., (1990); Wasserfallen, (1989)\}. Solnik (1987) employs monthly and quarterly data for eight industrial countries from 1973-1983 to examine the relation between real stock returns, exchange rates 
and reports a negative relation among variables. Soenen and Aggarwal (1989) re-assess this Solnik model using 1980-1987 data for the same industrial countries and report a positive correlation between stock returns and exchange rates for three countries and negative correlation for five. Employing monthly data, Aggarwal (1981) examines the relation between US stock market indexes and a trade weighted value of the dollar for the period 1974-1978 and finds that the stock prices and exchange rates are positively correlated. In contrast, Soenen and Hernigar (1988), also using monthly data, report a strong negative relation between US stock indexes and a fifteen currency weighted value of the dollar for the period 1980-1986.

The relationship between stock returns and interest rates in Sri Lanka studied by Premawardane (1997) found a negative relationship while in contrast Hasan et al. (2000) found a positive relationship. Bilson et al. (2001) tested whether local macroeconomic variables (money supply, goods prices and real activity) have explanatory power over stock returns in 20 exchange emerging markets for the period 1985-1997. The results indicate that the exchange rate variable is clearly the most influential macroeconomic variable, and money supply has greater importance. Panayotis et al. (1996) examined the impact of inflation uncertainty on stock prices in developed as well as in emerging capital markets for 20 countries and find a negative association between inflation uncertainty and stock prices. All the studies cited above represent various strong relationships between macroeconomic variables and stock returns in numerous countries. In this study the researcher is interested in documenting the effects of macroeconomic variables on stock prices in the Colombo Stock Exchange.

\section{Methodological Issues and Data Used}

This study investigates the effect of macroeconomic variables on stock prices. A number of researchers in various countries have found significant relationships between macroeconomic variables and stock prices. These studies concerned multi-factor models as well as single- factor models which incorporate macroeconomic variables as explanatory factors of the variation in equity returns. The following methodological approach is adopted in this study for establishing the relationship between macroeconomic variables and stock prices in the Emerging Sri Lankan Stock Market.

\subsection{Data}

The empirical analysis is carried out by using monthly data. The sample period spans from September 1991 to December 2002 and the study was carried out by using 136 monthly observations. The study uses stock prices which were collected from the Colombo Stock Exchange. After identifying the last trading day of each month, the monthly prices are defined as the natural logarithm of share prices at month $t$, as employed by Gjerde et al. (1998) and Chen et al. (2005).

\subsection{Sample}

Although there are 242 stocks listed on the CSE, most stocks do not trade frequently. In order to ensure a reasonable sample size, those stocks, which were traded at least once a month during the sample period, have been included in the sample. Further, attention was made on companies which were quoted by January 1991 and which had declared dividends throughout the sample period. 
On the basis of these three factors, a sample of 34 companies which is represented by eight sectors was selected.

\subsection{Variables}

A vast amount of studies document that significant relationships exist between macroeconomic variables and stock returns. Further, multi-factor models have been developed as an explanation for the variation in security returns and the extant literature suggests that a wide range of factors explain security returns \{Fama, 1981, Chen et al., 1986, 2005, Gjerde et al., 1999, and Bilson et al., 2001, Asprem (1989), Jenson et al. (1996), Abdullah and Hayworth, Bulmash and Trivoli (1989), Hooker (2004), Booth and Booth (1994), Wasserfallen (1989). Such variables include goods price, money supply, real activity, exchange rates, interest rates, political risks, oil prices, the trade sector, budget deficits, trade deficits, domestic consumption, unemployment rate, imports and regional stock market indices and real wage. In order to narrow the list of possible factors, their relevance to emerging stock markets is considered. In the light of the above considerations and balancing the theoretical propositions and prior evidence, four macroeconomic variables were selected. These variables are exchange rate, inflation rate, money supply, and interest rate. In a number of emerging market studies the above macroeconomic variables have been used to explain the variation in equity returns.

All these data are available on monthly basis. Numerous researchers have found that there is a lagged effect between macroeconomic variables and stock returns \{Samarakoon (1996); Gjerde et al. (1999); Chen (1991), Homa \& Jafee (1971); Bilson et al. (2001); Geske \& Roll (1983); Hooker (2004)\}. Thus, the researcher introduces lag variables into the model. However, the model employed in this study examines the power of four macroeconomic variables (with four lagged variables) in determining stock prices.

Inflation is measured by changes in the Colombo Consumer Price Index (CCPI) which was collected from Annual Reports of the Central Bank of Sri Lanka, and publications of the Department of Census and Statistics. The price index most relevant to the Irving Fisher effect is the one reflecting the actual prices paid by consumers. Thus, the researcher, along with many previous studies, made use of the Colombo Consumer Price Index (CCPI) as the measure of the price level. The monthly CCPI was computed as the natural logarithm of CCPI at month $t$ \{Gjerde et al. (1999)\}. The study uses three month primary market Treasury Bill Yield Rate as a measure of nominal interest rate. The T-Bill rate is calculated as the natural logarithm of three month T-Bill rate at month $t$. The researcher employed the nominal interest rate rather than the real rate of interest as Gjerde et al. (1999) employed. The money supply data consists of broad money supply $\left(M_{2}\right)$. In this empirical study the researcher used broad money supply, i.e. $M_{2}$, as money supply variable. Money supply variable was measured as the natural logarithm of month $t$ as Chen et al. (2005) employed. The researcher used the nominal exchange rate as a measure of exchange rate variable. The nominal exchange rate is defined as domestic currency units (Rs.) per unit of US dollar. The change in exchange rate is calculated as the natural logarithm of month $t$. 
The primary market Treasury Bill rate, broad money supply and exchange rate data were collected from the Monthly Bulletin of the Central Bank of Sri Lanka. In order to smooth the data all variables were converted to natural logarithm. The use of natural logarithm, rather than levels and percentage changes, mitigates these correlations among the variables. The use of SAS package to analyze the data eliminates the multi co-linearity using correlation matrix and stepwise analyze procedures were used.

\subsection{Development of Hypotheses}

This research observes the effects of macroeconomic variables on stock prices in the emerging Sri Lankan Stock Market. In order to achieve the objective of the study, the following hypotheses are developed.

Hypothesis 1: Money Supply and Stock Prices

$H_{1}$ : Money supply causes to increase the equity prices.

Hypothesis 2: Money Supply and Exchange Rate

$\mathrm{H}_{2}$ : Money supply and exchange rate together influence the behaviour of stock prices.

Hypothesis 3: Inflation Rate, Interest Rate, and Exchange Rate.

$H_{3}$ : Inflation rate, interest rate and exchange rate together cause to increase stock prices.

Hypothesis 4: Money Supply, Exchange Rate, Inflation Rate and Interest Rate

$\mathrm{H}_{4}$ : Money supply, exchange rate, inflation rate and interest rate together impact on equity price movements.

Hypothesis 5: Money Supply, Exchange Rate, Inflation Rate, Interest Rate, Lagged Money Supply and Lagged Inflation Rate.

$H_{6}$ : Money supply, exchange rate, inflation rate, interest rate, lagged money supply, lagged inflation rate altogether determine the stock prices.

\subsection{The Model}

This study examines the effect of macroeconomic variables on stock prices in selected companies in the CSE. Numerous researchers have developed multifactor models relating to a number of macroeconomic variables eg. Chen et al. (1986); Jorion, (1991); Ely and Robinson, (1997); Bilson et al., (2001). Chen et al. (2005)\} examined the relationship between macroeconomic variables and hotel stock returns and data were converted into natural log and used the regression analysis. Rangvid (2001) and Gjerde \& Saettem (1999) employed VAR framework and all data (macroeconomics variables) have been converted into natural logarithm. However, macroeconomic variables such as money supply, GDP, interest rate and exchange rate have been used in a number of ESM studies. There are several theoretical justifications to expect a relationship between macroeconomic variables and stock prices eg. Homa \& Jafee, (1971); Mandelker and Tandon, (1995); Boudoukh and Richardson, (1993)\}. Based on the model employed by Bilson et al. (2001) the researcher developed the following multiple regression model. 


$$
\begin{aligned}
& \ln S P_{i t}=\beta_{0 i}+\beta_{1} \ln M S_{i t}+\beta_{2} \ln E R_{i t}+\beta_{3} \ln C C P I_{i t}+\beta_{4} \ln T B R_{i t}+ \\
& \beta_{5} \ln M S_{i t-1}+\beta_{6} \ln C C P I_{i t-1}+\beta_{7} \ln M S_{i t-2}+\beta_{8} \ln C C P I_{i t-2}+\epsilon_{i t}
\end{aligned}
$$

Where, in is the natural logarithm, $\mathrm{SP}_{i t}$ is the stock prices of $\mathrm{i}^{\text {th }}$ company at time $\mathrm{t}, M S_{i t}$ is the money supply for company $\mathrm{i}$ at time $\mathrm{t}, E R_{i t}$ is the exchange rate for company $\mathrm{i}$ at time t, CCPI ${ }_{i t}$ is the inflation rate for company $i$ at time t, TBR ${ }_{i t}$ is the interest rate for company $\mathrm{i}$ at time $\mathrm{t}, M S_{i t-1}$ is the money supply for company $\mathrm{i}$ at time $\mathrm{t}-1$, $\mathrm{CCPI}_{i t-1}$ is the inflation rate for company $\mathrm{i}$ at time $\mathrm{t}-1, \mathrm{MS}_{i t-2}$ is the money supply for company $i$ at time $t-2, C C P I i t-2$ is the inflation rate for company $i$ at time $t-2, \beta_{0 i}$ is the intercept of the regression of $\mathrm{i}^{\text {th }}$ company, $\varepsilon_{\text {it }}$ is the error term of regression, $\beta_{1}, \beta_{2}$, $\beta_{3}, \beta_{4}, \beta_{5}, \beta_{6}, \beta_{7}$, and $\beta_{8}$ are the coefficient of variables. The overall statistical significance of regression is tested through $\mathrm{F}$-test.

\section{The Results}

\section{Overall Results}

This section presents the main results of regression on monthly data for the period from September 1991 to December 2002. The impact of macroeconomic variables on stock prices is estimated using four concurrent macroeconomic variables and four lagged variables taken together by employing a multiple regression model.

Table 1 reports the results from fitting the model as described in the equation in the methodology to each of the 34 companies $^{1}$. The results indicate that more than 27 companies out of 34 have higher explanatory power. All the variables are significant at $5 \%$ level rejecting the null hypothesis. Further, the results in Table 1 suggest that the macroeconomic variables representing lagged inflation rate and lagged money supply have only limited ability to explain the variation in equity prices. Money supply, inflation rate and interest rate have greater importance, while the most influential variable is the exchange rate. Negative relationships of macroeconomic variables are higher than positive relations. The signs of the coefficients on the exchange rate, contemporaneous inflation rate and interest rate variables are mainly negative.

The money supply variable is significant in ten companies (mainly positive as expected) while it is significantly negative for five companies. Interest rate is significantly negative for 14 companies and positive for 2 companies respectively. Further, inflation rate is also significant and negative for 15 companies while it is positive for 3 companies significantly. However, the exchange rate variable, the most influential variable, is significantly negative for 12 companies where as it is positive for 10 companies significantly. The lagged money supply and inflation rate variables are jointly significant for only 23 companies and they are mainly negatively related to stock prices.

1 The multiple regression was run with all variables measured contemporaneously and lagged money supply and inflation rate variables were given one month and two months lags to each of the 34 companies. 
The null hypotheses which suggest the coefficients on the macroeconomic variables (i.e., the money supply, exchange rate, inflation rate and interest rate) are equal to zero are rejected for all 34 companies at $5 \%$ significant level. The $\mathrm{R}^{2}$ values range between $38 \%$ and $98 \%$ which indicate higher explanatory power except in the case of one company.

Notably, the higher explanatory power tends to occur in trading and diversified sectors while lower explanatory power occurs in the food and beverage sector. Mostly, 27 companies out of 34 have higher explanatory power, i.e. more than $50 \%$. The model provides quite high explanatory power with an average $\mathrm{R}^{2}$ of $53 \%$. The variables that are able to explain stock price variation are common to most companies ${ }^{3}$. The model fit ranges from a low $\mathrm{R}^{2}$ of $7 \%$ in Tokyo Cement Ltd. to $98 \%$ in Heyleys Exports Ltd.

The money supply and lagged inflation by one month are significant only for 3 and 4 companies respectively. Consistent with the theory and empirical findings which indicate that negative relation with stock prices, the Treasury Bill rate impacts negatively for 14 companies. On the other hand, contemporaneous inflation has a negative relation with stock prices in 15 companies. Specially, in Banks \& Finance sector, money supply variable is common to 7 companies and out of this, 6 perform positively to stock prices while exchange rate is common to 6 companies out of which 5 reveal negative impact on stock prices. The coefficients of money supply and exchange rate are predominantly negative in diversified sector. Both contemporaneous inflation and lagged inflation rates are highly common to all companies in Motor sector, while inflation rate alone is significant in both Reckits \& Colman Ltd. and Aitken Spence Ltd.. Treasury Bill rate alone is highly significant in Tokyo Cement Company Ltd.

\section{Empirical findings - sector wise}

The empirical evidence is found that current money supply reacts mainly positively to stock prices except DFCC while the current exchange rate impacts predominantly negatively to stock prices in the Banking Sector, rejecting the null hypothesis at $5 \%$ level. The explanatory power of variables in explaining stock prices is more than $50 \%$. One unit increase in money supply will increase the stock prices by around one to two rupees except DFCC. Consistent with the commonly held view among economists, changes in money supply have important positive influences on stock prices and supporting the theory which means a direct impact on equity prices money supply reacts highly positively to stock prices in this sector. The beta coefficients of exchange rate are predominantly negative and very high indicating a value between $-1.7-7.2$ in six companies. This means that when the exchange rate rises by one unit the stock prices will drop by the contribution of the coefficient when other variables are held constant. On the other hand, current inflation and interest rate are significant in two companies only showing a negative impact to stock prices. This indicates that when inflation and interest rates rise, stock prices will drop. However, lagged money supply and lagged inflation rates could not predict current stock prices in this sector.

2 Tokyo Cement Company (Lanka Ltd.) reports the lowest $\mathrm{R}^{2}$ of $7 \%$.

3 The importance of each variable varies between companies and sectors and stepwise procedure results show the variables which have been found to be a greater importance for each company. 
In the manufacturing sector, the most significant variable is the interest rate which reacts negatively to stock prices. The magnitude of the coefficients are less than one, implying a little impact. Current money supply is highly significant and positive in four companies only with a magnitude around 2.1 to 3.7. However, Exchange Rate will react positively in one company while it negatively impacts in another company. On the other hand, two months lagged money supply and inflation rate negatively correlated with stock prices implying that future stock prices could be forecasted by using the past behaviour of these variables. The variables could jointly explain stock prices around $52 \%$ to $70 \%$ of much higher ability.

The stock prices appear to have a negative relation to money supply and exchange rate variables in the Diversified Sector. The contribution of the coefficients range from -1.3 to 4.4 showing a quite high impact. The stocks of Heyleys Ltd. provides an inflation hedge contributing a magnitude of 2.09 . The results show that the exchange rate variable is only highly significant $\left(R^{2}\right.$ is $\left.78 \%\right)$ with a negative beta of 1.6 in Aitken Spence \& Company Ltd.

Money Supply and exchange rate are positively correlated to stock prices in the Beverages Sector. When one unit increases in money supply exchange rate will lead to rise up stock prices by around one to two rupees. Like most of the companies in the sample, in this sector too, Treasury Bill rate responds negatively to stock prices with a beta of below one being other variables constant. However, variables are highly significant at $5 \%$ level rejecting the nullhypothesis and the ability of explaining stock price variation ranging from $51 \%$ $67 \%$.

In the Chemicals and Pharmaceutical sector money supply variable is significant only in Haycarb Ltd. showing a negative effect of 1.9. However, current inflation rate is highly affects stock prices with negative betas implying that in inflationary phase there will be a declining trend of stock prices in this sector. Interest rate is positively related with stock prices in Chemanex Ltd. while the relation shows a weak negative effect of 0.5 in Glaxo Welcome Ltd. Anyhow, the power of determining stock prices in this sector ranges from $42 \%-87 \%$.

Rejecting the null-hypothesis that the coefficients are not different from zero money supply, exchange rate, inflation rate and interest rate are highly significant in Hotels \& Travels sector. The strongest variable, exchange rate reacts negatively with a coefficient of 2.5 and 1.5 in Habarana Lodge Ltd. and Kandy Walk Inn Ltd. respectively. The stocks of Kandy Walk Inn Ltd. respond negatively to CCPI and Treasury Bill rate with magnitudes of 2.9 and 0.4 respectively and the variables jointly could explain average $\mathrm{R}^{2}$ of $57 \%$.

Table 1 - Macroeconomic model estimated on monthly prices by each company from September 1991 to December 2002.

This table reports the results of the multiple regression model. The variables are defined as; $\mathrm{SP}_{\mathrm{it}}$ - the Stock Price of $\mathrm{i}^{\mathrm{th}}$ company at time $\mathrm{t}, \mathrm{MS}_{\mathrm{it}}$ - the Money Supply for company $i$ at time $t, E R_{i t}$ - the Exchange Rate for company $i$ at time $t$, $\mathrm{CCPl}_{\text {it }}$ - the Colombo Consumer Price Index for company $\mathrm{i}$ at time $\mathrm{t}$, $\mathrm{TBR}_{\mathrm{it}}-3$ month Treasury Bill Rate for company $i$ at time $t$ and $t-1$ represents lagged inflation and money supply where $n=1,2$. $\beta_{\mathrm{o}}$ is the intercept of the regression. $P$ 
values which appear in parentheses are tests of the null hypotheses of the coefficients $\beta_{1}, \beta_{2}, \beta_{3}, \beta_{4}, \beta_{5}, \beta_{6}, \beta_{7}$ and $\beta_{8}$ are equal to zero. $R^{2}$ is the coefficient of determination adjusted for degrees of freedom. $F$ is the $F$ - Statistic for testing the overall significance of regression.

\section{In $S P_{i t}=\beta_{i}+\beta_{1} \ln M_{i t}+\beta_{2} \ln E R_{i t}+\beta_{3} \ln C C P I_{i t}+\beta_{4} \ln \mathrm{TBR}_{\mathrm{it}}+\beta_{5} \ln M S_{\mathrm{it}-1}+$} $\beta_{6}$ In $\mathrm{CCPI}_{\mathrm{it}-1}+\beta_{7} \ln \mathrm{MS} \mathrm{it}-2+\beta_{8} \ln \mathrm{CCPI}_{\mathrm{it}-2}$

\begin{tabular}{|c|c|c|c|c|c|c|c|c|c|c|c|}
\hline \multirow[b]{2}{*}{ 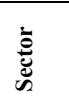 } & \multirow[b]{2}{*}{ 节 } & \multirow[b]{2}{*}{$\mathbf{R}^{2}$} & \multicolumn{9}{|c|}{ Regression Coefficient of Variables } \\
\hline & & & $\beta_{0}$ & $\beta_{1}$ & $\boldsymbol{\beta}_{2}$ & $\beta_{3}$ & $\boldsymbol{\beta}_{4}$ & $\beta_{5}$ & $\beta_{6}$ & $\boldsymbol{\beta}_{7}$ & $\boldsymbol{\beta}_{8}$ \\
\hline \multirow{2}{*}{ 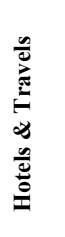 } & 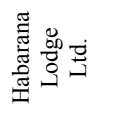 & 0.47 & $\begin{array}{l}15.697 \\
(0.0001)\end{array}$ & $\begin{array}{l}1.692 \\
(0.0077)\end{array}$ & $\begin{array}{l}-2.536 \\
(0.0001)\end{array}$ & & & & & & \\
\hline & 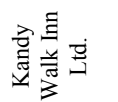 & 0.67 & $\begin{array}{l}20.726 \\
(0.001)\end{array}$ & & $\begin{array}{l}1.457 \\
(0.0206)\end{array}$ & $\begin{array}{l}-2.913 \\
(0.0001)\end{array}$ & $\begin{array}{l}-0.444 \\
(0.0137)\end{array}$ & & & & \\
\hline \multirow{3}{*}{ 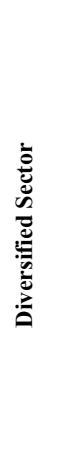 } & 离离 & 0.93 & $\begin{array}{l}20.956 \\
(0.0001)\end{array}$ & $\begin{array}{l}-1.281 \\
(0.0001)\end{array}$ & $\begin{array}{l}-3.282 \\
(0.0001)\end{array}$ & $\begin{array}{l}2.09 \\
(0.0001)\end{array}$ & $\begin{array}{l}-0.893 \\
(0.0001)\end{array}$ & & & & \\
\hline & 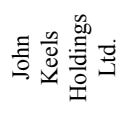 & 0.85 & $\begin{array}{l}17.351 \\
(0.0001)\end{array}$ & $\begin{array}{l}-4.401 \\
(0.0422)\end{array}$ & $\begin{array}{l}-1.507 \\
(0.0001)\end{array}$ & & & $\begin{array}{l}-0.809 \\
(0.0001)\end{array}$ & $\begin{array}{l}2.617 \\
(0.0007)\end{array}$ & & \\
\hline & 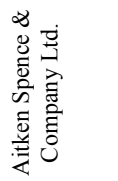 & 0.78 & $\begin{array}{l}17.522 \\
(0.0001)\end{array}$ & & & $\begin{array}{l}-1.646 \\
(0.001)\end{array}$ & & & & & \\
\hline \multirow{2}{*}{ 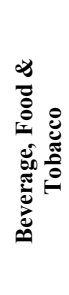 } & 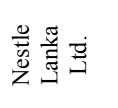 & 0.67 & $\begin{array}{l}-0.838 \\
(0.5733)\end{array}$ & $\begin{array}{l}1.764 \\
(0.0001)\end{array}$ & $\begin{array}{l}2.146 \\
(0.0001)\end{array}$ & $\begin{array}{l}-3.342 \\
(0.0001)\end{array}$ & $\begin{array}{l}-0.317 \\
(0.0176)\end{array}$ & & & & \\
\hline & 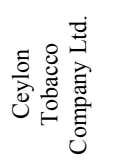 & 0.51 & $\begin{array}{l}13.076 \\
(0.0001)\end{array}$ & & $\begin{array}{l}1.235 \\
(0.0001)\end{array}$ & & $\begin{array}{l}-0.839 \\
(0.0001)\end{array}$ & & & $\begin{array}{l}-1.030 \\
(0.0001)\end{array}$ & \\
\hline
\end{tabular}




\begin{tabular}{|c|c|c|c|c|c|c|c|c|c|c|c|}
\hline \multirow{7}{*}{ 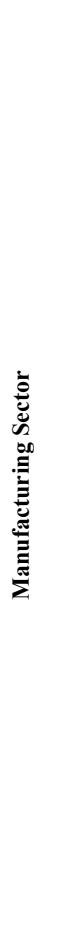 } & 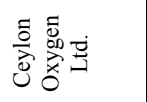 & 0.65 & $\begin{array}{l}12.661 \\
(0.0001)\end{array}$ & & & & $\begin{array}{l}-0.385 \\
(0.0195)\end{array}$ & & & $\begin{array}{l}-0.756 \\
(0.0001)\end{array}$ & \\
\hline & 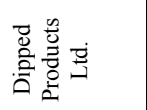 & 0.69 & $\begin{array}{l}5.242 \\
(0.0001)\end{array}$ & $\begin{array}{l}2.585 \\
(0.0057)\end{array}$ & $\begin{array}{l}-2.747 \\
(0.0001)\end{array}$ & & $\begin{array}{l}-0.205 \\
(0.0349)\end{array}$ & & $\begin{array}{l}2.101 \\
(0.0001)\end{array}$ & & \\
\hline & 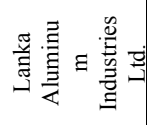 & 0.52 & $\begin{array}{l}16.528 \\
(0.0001)\end{array}$ & $\begin{array}{l}3.791 \\
(70.0001)\end{array}$ & $\begin{array}{l}-2.950 \\
(0.0032)\end{array}$ & & & & & $\begin{array}{l}-0.600 \\
(0.0433)\end{array}$ & \\
\hline & 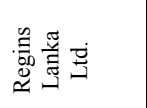 & 0.67 & $\begin{array}{l}12.663 \\
(0.0001)\end{array}$ & & $\begin{array}{l}2.334 \\
(0.0001)\end{array}$ & $\begin{array}{l}-1.650 \\
(0.0066)\end{array}$ & & $\begin{array}{l}0.580 \\
(0.0314)\end{array}$ & & & $\begin{array}{l}-1.794 \\
(0.0013)\end{array}$ \\
\hline & 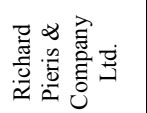 & 0.69 & $\begin{array}{l}20.615 \\
(0.0001)\end{array}$ & & & & $\begin{array}{l}-0.768 \\
(0.0001)\end{array}$ & & $\begin{array}{l}2.307 \\
(0.0005)\end{array}$ & $\begin{array}{l}-2.543 \\
(0.0001)\end{array}$ & \\
\hline & 織 & 0.70 & $\begin{array}{l}21.834 \\
(0.0001)\end{array}$ & $\begin{array}{l}2.148 \\
(0.0010)\end{array}$ & $\begin{array}{l}2.644 \\
(0.0003)\end{array}$ & $\begin{array}{l}-3.055 \\
(0.0351)\end{array}$ & & & & & $\begin{array}{l}-4.350 \\
(0.0014)\end{array}$ \\
\hline & 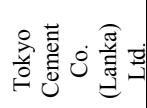 & 0.07 & $\begin{array}{l}5.909 \\
(0.0001)\end{array}$ & & & & $\begin{array}{l}-0.7222 \\
(0.0023)\end{array}$ & & & & \\
\hline \multirow{3}{*}{ 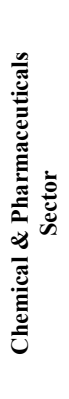 } & 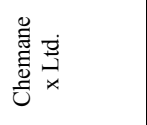 & 0.42 & $\begin{array}{l}13.467 \\
(0.0001)\end{array}$ & & & $\begin{array}{l}-1.096 \\
(0.0001)\end{array}$ & $\begin{array}{l}0.513 \\
(0.0019)\end{array}$ & & & & \\
\hline & 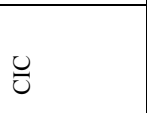 & 0.86 & $\begin{array}{l}4.845 \\
(0.0001)\end{array}$ & & & $\begin{array}{l}-0.457 \\
(0.0001)\end{array}$ & & & & & \\
\hline & 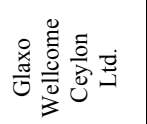 & 0.67 & $\begin{array}{l}16.291 \\
(0.0001)\end{array}$ & & $\begin{array}{l}2.309 \\
(0.0001)\end{array}$ & & $\begin{array}{l}-0.478 \\
(0.0001)\end{array}$ & $\begin{array}{l}-1.125 \\
(0.0001)\end{array}$ & & & $\begin{array}{l}-0.907 \\
(0.0379)\end{array}$ \\
\hline
\end{tabular}




\begin{tabular}{|c|c|c|c|c|c|c|c|c|c|c|}
\hline \multirow{2}{*}{ 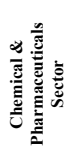 } & 喜这 & 0.74 & $\begin{array}{l}14.610 \\
(0.0001)\end{array}$ & $\begin{array}{l}-1.927 \\
(0.0001)\end{array}$ & $\begin{array}{l}-1.299 \\
(0.0032)\end{array}$ & $\begin{array}{l}-2.12 \\
(0.0006)\end{array}$ & & & & \\
\hline & 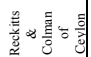 & 0.87 & $\begin{array}{l}16.567 \\
(0.0001)\end{array}$ & & & $\begin{array}{l}-1.674 \\
(0.0001)\end{array}$ & & & & \\
\hline \multirow{8}{*}{ 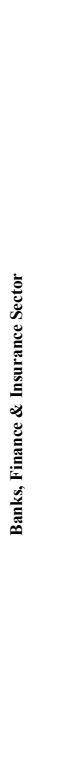 } & 焉- & 0.86 & $\begin{array}{l}12.375 \\
(0.0001)\end{array}$ & & $\begin{array}{l}-5.976 \\
(0.0001)\end{array}$ & & $\begin{array}{l}-1.132 \\
(0.0001)\end{array}$ & & $\begin{array}{l}1.642 \\
(0.0001)\end{array}$ & \\
\hline & 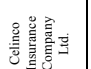 & 0.58 & $\begin{array}{l}14.464 \\
(0.0001)\end{array}$ & $\begin{array}{l}1.803 \\
(0.0001)\end{array}$ & $\begin{array}{l}-1.764 \\
(0.0012)\end{array}$ & $\begin{array}{l}-2.538 \\
(0.0093)\end{array}$ & $\begin{array}{l}-0.414 \\
(0.0070)\end{array}$ & & & $\begin{array}{l}-2.7 .2 \\
(0.0037)\end{array}$ \\
\hline & 居 & 0.90 & $\begin{array}{l}34.717 \\
(0.0001)\end{array}$ & $\begin{array}{l}-2.347 \\
(0.0001)\end{array}$ & & & & & & \\
\hline & 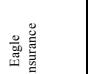 & 0.50 & $\begin{array}{l}1.14 \\
(0.4553)\end{array}$ & $\begin{array}{l}1.589 \\
(0.0001)\end{array}$ & $\begin{array}{l}-4.170 \\
(0.0001)\end{array}$ & & & & & \\
\hline & $\underline{\underline{z}}$ & 0.94 & $\begin{array}{l}10.594 \\
(0.0001)\end{array}$ & $\begin{array}{l}1.951 \\
(0.0001)\end{array}$ & $\begin{array}{l}-7.215 \\
(0.0001)\end{array}$ & & & & & \\
\hline & 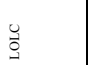 & 0.79 & $\begin{array}{l}9.559 \\
(0.0001)\end{array}$ & $\begin{array}{l}1.555 \\
(0.0001)\end{array}$ & $\begin{array}{l}-5.933 \\
(0.0001)\end{array}$ & & & & & \\
\hline & 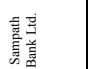 & 0.52 & $\begin{array}{l}-3.461 \\
(0.0070)\end{array}$ & $\begin{array}{l}1.322 \\
(0.0001)\end{array}$ & $\begin{array}{l}-2.074 \\
(0.0001)\end{array}$ & $\begin{array}{l}-0.243 \\
(0.0347)\end{array}$ & & & & \\
\hline & 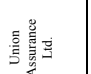 & 0.59 & $\begin{array}{l}10.129 \\
(0.0001)\end{array}$ & $\begin{array}{l}1.123 \\
(0.0001)\end{array}$ & & $\begin{array}{l}-1.9 .9 \\
(0.0001)\end{array}$ & & & & \\
\hline \multirow{2}{*}{ 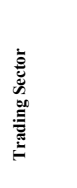 } & 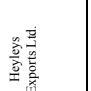 & 0.98 & $\begin{array}{l}2.575 \\
(0.0384)\end{array}$ & $\begin{array}{l}-0.414 \\
(0.0001)\end{array}$ & $\begin{array}{l}-1.512 \\
(0.0002)\end{array}$ & & $\begin{array}{l}0.368 \\
(0.0009)\end{array}$ & $\begin{array}{l}1.513 \\
(0.000 \\
1)\end{array}$ & & \\
\hline & 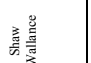 & 0.79 & $\begin{array}{l}32.243 \\
(0.0001)\end{array}$ & & $\begin{array}{l}6.905 \\
(0.0001)\end{array}$ & & $\begin{array}{l}-0.732 \\
(0.0001)\end{array}$ & & $\begin{array}{l}-2.721 \\
(0.0001)\end{array}$ & $\begin{array}{l}-2.809 \\
(0.0004)\end{array}$ \\
\hline
\end{tabular}




\begin{tabular}{|c|c|c|c|c|c|c|c|c|}
\hline 逽 & 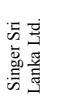 & 0.83 & $\begin{array}{l}8.691 \\
(0.0001)\end{array}$ & $\begin{array}{l}-1.796 \\
(0.0001)\end{array}$ & $\begin{array}{l}-1.724 \\
(0.0006)\end{array}$ & & $\begin{array}{l}1.271 \\
(0.0001)\end{array}$ & \\
\hline \multirow{3}{*}{ 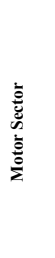 } & $\bar{\Delta} \Sigma 0$ & 0.72 & $\begin{array}{l}16.065 \\
(0.0001)\end{array}$ & & $\begin{array}{l}-2.463 \\
(0.0304)\end{array}$ & & $\begin{array}{l}0.258 \\
(0.0001)\end{array}$ & $\begin{array}{l}2.794 \\
(0.0101)\end{array}$ \\
\hline & $<\Sigma z$ & 0.81 & $\begin{array}{l}29.803 \\
(0.0001)\end{array}$ & $\begin{array}{l}3.587 \\
(0.0001)\end{array}$ & $\begin{array}{l}-3.268 \\
(0.0002)\end{array}$ & $\begin{array}{l}-0.611 \\
(0.0001)\end{array}$ & $\begin{array}{l}-1.135 \\
(0.0120)\end{array}$ & \\
\hline & 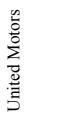 & 0.39 & $\begin{array}{l}312.185 \\
(0.0001)\end{array}$ & & $\begin{array}{l}80.378 \\
(0.0001)\end{array}$ & $\begin{array}{l}-17.790 \\
(0.0001)\end{array}$ & $\begin{array}{l}-67.647 \\
(0.0001)\end{array}$ & \\
\hline
\end{tabular}

First row - Regression Coefficients

All the variables in the model are significant at 0.05 level.

\section{Conclusion, Implications and future Research Directions}

This study investigated the effects of macroeconomic variables on stock prices in Sri Lanka using monthly data for the period from September 1991 to December 2002. A multiple regression model was used to find out relationships and for examining the impact of macroeconomic variables on stock prices. The fitted regression model reveals strong relationships between macroeconomic variables and stock prices. The results indicate that 27 stocks out of 34 have higher explanatory power of more than $50 \%$ in the monthly stock prices for the period 1991-2002, the period which provides the strongest evidence of predictability of macroeconomic variables on stock prices. The key finding is that the null hypotheses which suggest the coefficients of the variables do not make any impact on stock prices is rejected for all 34 stocks.

The stock prices mainly appear to have an inverse relation to exchange rate, concurrent inflation rate and Treasury Bill rate in the CSE. Consistent with the theory which indicates a direct relation, money supply is mainly positively related to stock prices. This result supports the findings of Bilson et al. (2001), Lynge (1981) and Roley (1982). Chen et al. (2005), Bulmash and Trivoli (1991) and Barrows and Naka (1994) that find a positive relation between money supply and stock returns. Rozeff (1984), Campbell (1987), Kaul (1987) and Booth and Booth (1997), confirmed the theory that an expansionary monetary policy increases stock returns. The most significant variable-the exchange rate- is mainly negative to stock prices supporting the findings of Solnik (1987) and Soenen \& Hernigar (1988) and Bilson et al. (2001). It is found that most of the companies, i.e. 15 stocks out of 34 expose a strong negative relation between stock prices and inflation rate. These findings are consistent with similar results of Fama (1981, 1982), Gallagher and Taylor (2002) Geske and Roll (1983), Apergis and El, (2002), Omran and Poton (2001), Crosby (2001), Fama \& Schwert (1977), Gjerde et al. (1999) in developed country studies as well as emerging country studies. Stock prices react negatively to Treasury Bill rate in 14 companies consistent with the theory which implies that risk free interest rate is negatively related to stock prices and consistent with the findings of Geske and Roll (1983), Bulmash \& Trivoli (1991), Gjerde et al. (1999), Abdullah and Hayworth (1993), Asprem (1989), Wasserfallen (1989) and Koch et al. (2001). However, this finding is inconsistent with the findings by Premawardena (1997) and Hasan et al. (2000) which shows a positive relation in the Sri Lankan context. The lagged money supply variables appear to have a negative effect on stock prices in eight 
companies in the sample, inconsistent with Efficient Market Hypothesis which indicates that current stock prices contain all available information. These findings are compatible with Sprinkel (1964), Homa \& Jafee (1971) and Hamburger \& Kochin (1972). On the other hand, one month lagged inflation is positively co-related to stock prices in four companies supporting the Fisher Hypothesis which implies that stocks of these companies provide effective inflation hedge. This finding is compatible with the results of Samarakoon (1996), Firth (1981) and Bilson et al. (2001).

The negative and positive effects of macroeconomic variables on stock prices found in this study have several practical implications. The evidence provides that stock prices appear to react mainly negatively to rising interest rates. One reason suggested for this relation is the expected returns on stocks on which the higher interest rate has a direct bearing. Thus, the higher interest rates would directly affect the returns on stocks causing prices to fall consistent with the theory. Whenever the interest rate on treasury securities increases, the investors tend to switch out of stocks causing fall of stock prices. Therefore, this implies that a certain level of predictability is present in stock prices that can be explained through the behaviour of the three month Treasury Bill rate.

The money supply which reacts mainly positively to stock prices has implications on monetary policy in which the changes in money supply will have a direct impact on equity prices. Since the monetary policy should not be guided by the impact on the stock market, such influences should not be ignored as a result of the influence of the stock market on economic activity. On the other hand, the lagged money supply mainly appears to have a negative impact on equity price movements implying that investors could earn profits by using a trading strategy based on the past behaviour of the money stock.

The exchange rate variable is clearly the most influential macroeconomic variable, which displays mainly a negative relation to stock prices. The implication of this finding is that, for an export dominant economy, (exports companies listed on the CSE), the currency appreciation has a negative effect on the stock market of which the currency appreciation boosts the stock market for an import dominant economy (imports companies listed in the CSE).

The regression results obtained in deriving the estimates seem to indicate that, contrary to a commonly held belief among economists, the equity prices are mainly negatively related to contemporaneous inflation. This finding implies that the stock prices decline during the inflationary phase.

The results have implications on both local and foreign investors, stock market regulators such as Securities and Exchange Commission, policy makers and stock market analysts. Investors and security analysts could predict stock prices and earn profits. Stock market regulators could take steps to monitor the activities of companies to prevent manipulation of stock prices and get the general public educated on the stock market and encourage them to invest in stocks. Policy makers should be aware of these macroeconomic effects on stock market and make their decisions in a more effective and accurate way.

The results of this study are based on the data sets, which are of high quality. Future researchers can investigate the effect of macroeconomic variables on stock prices using alternative methodologies and using sectoral share price indices. Further, they can use data of various frequencies such as daily and 
weekly and examine whether the results are sensitive to the frequency of data. Other aspects on which future researchers can concentrate on are the longer time periods, larger sample sizes with greater numbers of sectors using other macroeconomic and non-macroeconomic variables.

\section{References}

Aggarwal, R. 1981. Exchange rate and stock prices. A Study of US Capital Markets Under Floating Exchange Rates, Akron Business and Economic Review 12(2), 7-12.

Asprem, M., 1989. Stock prices, asset portfolios and macroeconomic variables in ten European countries. Journal of Banking and Finance 13 (4/5), 589-612.

Barrows, C.W., Naka, A., 1994. Use of macroeconomic variables to evaluate selected hospitality stock returns in the US. International Journal of Hospitality Management 13 (2), 119-128.

Bilson, C. M., Brailsford, T. J., \& Hooper, V. J. 2001. Selecting macroeconomic variables as explanatory factors of emerging stock market returns. Pacific-Basin Finance Journal, 9(4), 401-426.

Booth, J.R., Booth, L.C., 1997. Economic factors, monetary policy and expected returns on stocks and bonds. Economic Review-Federal Reserve Bank of San Francisco 2, 32-42.

Boudoukh, J., Richardson, M., 1993. Stock returns and Inflation. A Long-horizon Perspective, American Economic Review 83, 1346-1355.

Bulmash, S.B., Trivoli, G.W., 1991. Time-lagged interactions between stock prices and selected economic variables. Journal of Portfolio Management 17 (4), 61-67.

Cauchie, S., Hoesli, M., Isakov, D., 2004. The determinants of stock returns in a small open economy. International Review of Economics and Finance, 13 (2004) $167-185$.

Chatrath, A., Ramchander, S., \& Song, F. 1997. Stock prices, inflation and output: Evidence from India. Applied Financial Economics, 7, 439-445.

Chen, M.H., Kim, W.G., Kim, H.J., 2005. The impact of macroeconomic and nonmacroeconomic forces on hotel stock returns. Hospitality Management 24 (2005) 243-258.

Chen, N., Roll, R., Ross, S.A., 1986. Economic forces and the stock market. Journal of Business 59 (3), 383-403.

Choudhry, T. 2000. Inflation and rates of return on stocks: Evidence from high inflation countries. Journal of International Financial Markets, Institutions, and Money, 11, 75-96.

Crosby, M. 2000. Stock returns and inflation. Australian Economic Papers. 40, 156-165. 
Ely, D.P., and Robinson., K.J., 1997. Are stocks a hedge against inflation? international evidence using a long-run approach. Journal of International Money and Finance 16, 141-167.

Engsted, T., Tanggaard, C., 2002. The relation between asset returns and inflation at short and long horizons. Journal of International Financial Markets, Institutions \& Money 12, 101-118.

Fama, E., F, 1990. Stock returns, expected returns, and real activity. Journal of Finance 45, 1089-1108.

Fama, E.F., 1981. Stock returns, real activity, inflation and money. American Economic Review 71 (4), 545-565.

Fama, E.F., French, K.R., 1988. Dividend yields and expected stock returns. Journal of Financial Economics 22 (1), 3-25.

Gallagher, L. A., \& Taylor, M. P. 2002. The stock return-inflation puzzle revisited. Economics Letters, 75, 147-156.

Geske, R., \& Roll, R. 1983. The monetary and fiscal linkage between stock returns and inflation. Journal of Finance, 38, 1-33.

Gjerde, O., and Saettem, F., 1999. Causal relations among stock returns and macroeconomic variables in a small open economy. Journal of International Financial Markets, Institutions and Money 9, 61-74.

Harvey, C.R., 1995b. Predictable risk and return in emerging markets. Review of Financial Studies 8, 773-816.

Hasan, T., Samarakoon, L.P., and Hasan, S., 2000. Stock prices behaviour in a less developed market; evidence from Sri Lanka. Journal of Applied Business Research, Vol. 16, No.02, 15-23.

Homa, K.E., \& Jaffee, D.M., 1971. The supply of money and common stock prices. Journal of Finance 26, 1045-1066.

Hondroyiannis, G., \& Papapetrou, E. 2001. Stock market performance and macroeconomic experience in Greece. Greek Economic Review, 21(2), 65-84. In, F., Kim, S. The hedge ratio and the empirical relationship between the stock and futures markets: a new approach using wavelength analysis. Journal of Business (in press).

Karolyi, A. G., \& Stulz, R. M. 2003. Are financial assets priced locally or globally? in Handbook of the economics of finance, G. Constantinides, M. Harris, \& R. M. Stulz (eds.) Amsterdam: North Holland.

Kaul, G. 1990. Monetary regimes and the relation between stock returns an inflationary expectations. Journal of Financial and Qualitative Analysis, 25, 307321.

Kaul, G., 1987. Stock returns and inflation: The Role of the Monetary Sector. Journal of Financial Economics, 18, 253-276. 
Kim, S., In, F., 2005. The relationship between stock returns and inflation: new evidence from wavelet analysis. Journal of Empirical Finance 12 (2005) 435-444.

Lee, B. 1992. Causal relationships among stock returns, interest rates, real activity, and inflation. Journal of Finance, 38, 1591-1603.

Mandelker, G., Tandon, K., 1985. Common stock returns, real activity, money and inflation, some international evidence, Journal of International Money and Finance 4, 267-286.

Najand, M., \& Noronha, G. 1998. Causal relations among stock returns, inflation, real activity and interest rates: Evidence from Japan. Global Finance Journal, 1, 71-80.

Nimal, P.D., 1997. Relationship between stock returns and selected fundamental variables, Evidence from Sri Lanka. Sri Lankan Journal of Management., Vol 2, No.3, 269-287.

Omran, M., \& Pointon, J. 2001. Does the inflation rate affect the performance of the stock market? The case of Egypt. Emerging Markets Review, 2, 263-279.

Premawardhana, V., 1997. The relationship between stock returns and interest rates in Sri Lanka. Sri Lankan Journal of Management 3, 251 - 263.

Rangvid, J., 2001. Predicting returns and changes in real activity; Evidence from Emerging Economies. Emerging Markets Review 2, 309-329.

Rapach, D. E. 2002. The long-run relationship between inflation and real stock prices. Journal of Macroeconomics, 24, 331-351.

Rapach, D.E., 2001. Macro shocks and real stock prices, Journal of Economics and Business 53, 5-26.

Samarakoon, L.P., 1996b. Stock market returns and inflation: Sri Lankan Evidence. Sri Lankan Journal of Management 1, 293 - 311.

Solnik, B., Solnik, V., 1997. A multi-country test of the fisher model for stock returns. Journal of International Financial Markets, Institutions \& Money 7, 289301.

Wasserfallen, W., 1989. Macroeconomic news and the stock market. Journal of Banking and Finance 13 (4/5), 613-626.

Zhao, X. 1999. Stock prices, inflation and output: Evidence from China. Applied Economics Letters, 6, 509-511. 